DOI: https://doi.org/10.24144/2409-6857.2019.1(53).212-220

УДК 657.01

Голочалова И.Н., Цуркану В. И.

\title{
КОНЦЕПЦИИ ФОРМАТА КОНСОЛИДАЦИИ ФИНАНСОВОЙ ОТЧЕТНОСТИ: МЕЖДУНАРОДНЫЙ И НАЦИОНАЛЬНЫЙ АСПЕКТЫ
}

\begin{abstract}
Экономический эффект объединения бизнеса находит свое отображение в консолидированной финансовой отчетности, назначение которой в представлении полезной информации пользователям для принятия управленческих решений. В контексте эволючии методологии бухгалтерского учета и финансовой отчетности выделилось ее два направления - европейский и международный, каждому из которых свойственен соответственный подход подготовки финансовой отчетности: юридический и экономический. Следствием отличия в этих подходах, и в первую очередь ориентацией информации на определенную группу пользователей, явилось различие концепџий установления формата консолидации финансовой отчетности. В данном исследовании авторами выдвигается гипотеза о действенности $в$ современной методологии бухгалтерского учета двух концепций установления формата консолидации концепции контроля и концепџии управления. В статье гипотеза: обосновывается положениями международной нормативной базы и нормативной базы Республики Молдова в отношении консолидации отчетности; доказывается разработкой алгоритма установления формата контроля при консолидации согласно МСФО, и определением роли контроля в рамках каждой из выделенных концепций.
\end{abstract}

Ключевые слова: консолидированная финансовая отчетность, концепщия контроля, конщепция управления, экономический подход, юридический подход, методология бухгалтерского учета

Постановка проблемы. Одним из институционально закрепленных направлений организации бизнес-структур, является объединение предприятий, основанием которого служит слияние их промышленного, а подчас и финансового капиталов. Несмотря на факт того, что цель деятельности любого предприятия (бизнес-единицы) - это получение прибыли, задачи бизнес-структур достаточно многообразны: от получения экономической выгоды в краткосрочной перспективе до полного контроля за деятельностью бизнес-единиц. Решение этих задач осуществляется на базе оптимального соотношения правомочий в рамках бизнес-структуры, что приводит к возникновению разных ее форм и моделей.

Как известно, экономический эффект от объединения капиталов бизнеса находит свое отображение в консолидированной финансовой отчетности, назначение которой в представлении полезной информации пользователям для

( Голочалова И. Н., доктор экономических наук, доцент Департамента бухгалтерского учета и экономической информатики, Государственный Университет Молдовы, г. Кишинев (Молдова) тел:+37360287573, E-mail: monomah5@yandex.ru Цуркану В. И., доктор хабилитат экономических наук, профессор Департамента бухгалтерского учета и экономической информатики, Государственный Университет Молдовы, г. Кишинев (Молдова),тел:+37379662011, E-mail: vturcanu@mail.ru принятия управленческих решений. Однако в контексте эволюции методологии бухгалтерского учета и финансовой отчетности выделилось ее два направления - европейский и международный, каждому из которых свойственен особый подход подготовки финансовой отчетности: при европейской (континентальной) модели учета превалирует юридический подход, отсюда и требование точности финансовой отчетности, а при международной (англо-саксонской) модели учета - экономический подход и акцент поставлен на достоверности информации. Следствием отличия в этих подходах, и в первую очередь ориентацией информации на определенную группу пользователей, явилось различие концепций установления формата консолидации финансовой отчетности.

Актуальность данного исследования обусловлена необходимостью изучения этих концепций с целью унификации методологического приема установления формата консолидации, что требует научной аргументации.

Анализ последних достижений и публикаций. Исследованию вопроса консолидации финансовой отчетности посвящены работы таких ученых как: Д. Александер, Я. Крупка, Я. Соколов, Н. Фелягэ, Дж. Эдвардс и др. Значительный вклад в проблему внесли ученые-экономисты: Балтарю К.-Ал. (C.-Al. Baltariu), Кырстя А. (A. Cirstea) [13] (Румыния), В. Плотников [4], Ю. Сигидов [5] (Россия), Воскало В. (V. Voskalo) [14] (Украина). 
Ряд авторов акцентирует внимание на проблемах подготовки консолидированной отчетности, которые обусловлены процессом гармонизации системы бухгалтерского учета. Так, ученый-экономист Сигидов Ю. считает, что консолидированная отчетность является продуктом мировой экономической системы, относя к факторам, обусловивших процесс консолидации, формы финансирования бизнеса и становление профессионального менеджмента [5, c. 310]. Данной трактовки в своих работах придерживается Генералова Н., раскрывая этот вопрос через призму эволюции нормативного регулирования данного вида отчетности [3, с. 97]. Другие исследования направлены на выявление проблем, связанных с внедрением на практике теорий и методов консолидации. В этом контексте интересным представляется исследование Балтариу К.-Ал. (C.-Al. Baltariu), в рамках которого проводится статистический анализ сегментирования групп организаций на действующем рынке Румынии на базе расчета индекса Герфиндаля с использованием показателя гудвилла - элемента консолидированной отчетности, и рассчитанного методами, рекомендованными в системе МСФО $[13$, с. 316]. Отдельного внимания заслуживает работа Воскало В. (V. Voskalo), по мнению которого одной из проблем консолидации определение статуса организаций, входящих в объединения, которая обусловлена как отличием в национальных моделях организации бухгалтерского учета, так и разницей в формах финансовых инструментов, подтверждающих право на долю участия [14, с. 532]. В специальной литературе широко представлено сравнение национальных и международных подходов подготовки консолидированной отчетности.

Часть исследований проведено на микроуровне и связано с уточнением: понятия «консолидированная отчетность», в основу которого должны быть положены правоотношения на базе контроля или других конкретных связей по группе организаций $[2, \mathrm{c}$. 126]; трактовки инвесторов, которые в контексте введения новой модели контроля при консолидации, идентифицируются на контролирующие объект инвестиций и с неконтролирующей долей участия, но имеющие равные права на возврат с инвестиции, только в разных объемах [4, с. 11], [3, с. 98]. Все эти исследования несомненно способствуют развитию методологии консолидированной отчетности. Не обошли вниманием эту проблему и авторы данного исследования: [6].
Тем не менее, существует ряд дискуссионных вопросов, один из которых направлен на унификацию формата контроля при консолидации.

Формулирование целей исследования. В данном исследовании авторами выдвигается гипотеза: в современной методологии бухгалтерского учета действуют две кониепџии установления формата консолидации: концепция контроля (международная модель учета) $u$ концепиия управления (европейская модель учета). Для аргументации гипотезы первым аспектом исследования обозначено изучение международной и национальной (на примере Республики Молдова) нормативной базы в отношении консолидации отчетности, вторым методическим аспектом является раскрытие приемов установления формата контроля при консолидации согласно двум моделям бухгалтерского учета и отчетности. Общая характеристика концепций формата консолидации и определение роли контроля в рамках каждой из них - это третий (методологический) аспект данного исследования.

Описание основного

материала исследования. Формирование и поддержание конкурентных преимуществ любой бизнесединицы в условиях перехода на инновационный путь развития возможно только при обеспеченности ресурсами (материальными, финансовыми, человеческими), что при их общем ограничении достаточно проблематично. Одним из путей решения этой проблемы является институционально-закрепленная организация бизнес-структуры, основанная на объединении ресурсов предприятий через слияние их капиталов. Принято считать, что бизнес-единица (предприятие), входящая в объединение, получает возможность использовать технологии ноу-хау, расширять сферу своей деятельности, укреплять деловые связи, способствовать своему инвестиционному потенциалу. Менеджмент бизнес-структуры, a также еe собственники (акционеры и инвесторы) требуют специфических данных и информации. Для удовлетворения этих информационных потребностей разработаны специальные подходы подготовки финансовой отчетности, получившей название консолидированная отчетность.

Значение консолидированной отчетности проявляется и в том внимании, которое уделяется установлению формата консолидации по определенным методическим приемам, что находит отражение в юрисдикциях отдельных стран. Однако существенные отличия в 
национальных правилах консолидации отчетности обусловили необходимость ее межнационального регулирования. Так, в 2013 году введены в действие Директива 2013/34/EC, а в рамках МСФО - IFRS 10 «Консолидированная финансовая отчетность» и IFRS 11 «Соглашения о совместной деятельности», положения которых регламентируют порядок установления формата контроля при консолидации.

В контексте Соглашения об Ассоциации с Европейским Союзом (2014 г.) Республика Молдова приняла ряд обязательств, в том числе и в части реформирования законодательной и нормативной базы в области бухгалтерского учета, исполнение которых направлено на глубокую экономическую и политическую интеграцию. Во исполнение данных обязательств в Республике Молдова (РМ) с 01.01.2019 г. введен новый закон бухгалтерского учета - Закон № 287 от 15.12.2017 года «О бухгалтерском учете и финансовой отчетности», в котором обозначены основные понятия в отношении консолидированной отчетности и в отдельной главе изложены требования к ее содержанию и представлению. Кроме этого были внесены изменения в части правоотношений в условиях инвестирования в ряд законов: Гражданский кодекс РМ № 1107 от 06.06.2002, Закон об акционерных обществах №1134 - XIII от 02.04.1997 г.; Закон о рынке капитала № 171 от 11.07.2012. В контексте мероприятий по бухгалтерскому учету, предусмотренных Соглашением об ассоциации ЕС-РМ в 2017 году в Министерстве финансов был обсужден проект НСБУ «Представление консолидированных финансовых отчетов», который подготовлен на базе IFRS 10 «Консолидированная финансовая отчетность».

Традиционно принято считать, что обладание контролем одной из объединяющихся бизнесединиц возможно при приобретении более половины имеющих право голоса акций другой. Приведем понятия в отношении установления формата контроля при консолидации и раскроем их содержание согласно Директиве 2013/34/EC, международным стандартам - IFRS 10 и IFRS 11 и законодательной базе РМ (табл. 1).

\begin{tabular}{|c|c|c|c|}
\hline \multirow{2}{*}{$\begin{array}{c}\text { Поня- } \\
\text { тия } \\
\end{array}$} & \multicolumn{3}{|c|}{ Определение понятий } \\
\hline & Директива 2013/34/EC [12] & IFRS 10 и IFRS 11 [11] & Законы и НСБУ РМ \\
\hline 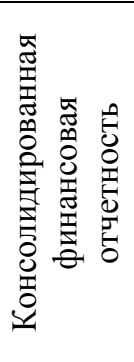 & $\begin{array}{l}\text { представляет деятельность } \\
\text { материнской компании и } \\
\text { ее дочерних компаний как } \\
\text { деятельность единого } \\
\text { хозяйствующего субъекта } \\
\text { (группы) }\end{array}$ & $\begin{array}{l}\text { это финансовая отчетность } \\
\text { группы, в которой активы, } \\
\text { обязательства, капитал, доходы и } \\
\text { расходы, и потоки денежных } \\
\text { средств материнского и дочернего } \\
\text { предприятий представлены как для } \\
\text { единого субъекта экономической } \\
\text { деятельности }\end{array}$ & 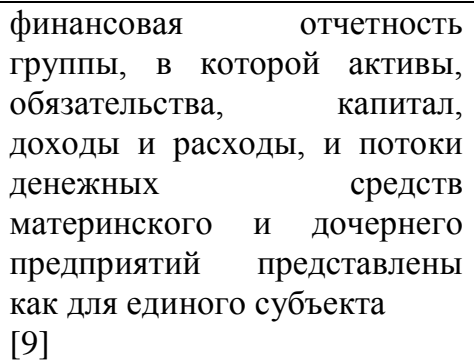 \\
\hline 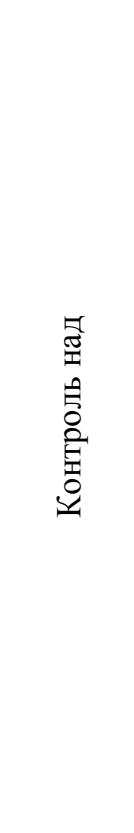 & \begin{tabular}{|l} 
предприятием основан: \\
- владении большинством \\
голосующих акций; \\
праве акционера \\
дазначать или смещать с \\
должности большинство \\
членов \\
административного, \\
управляющего или \\
контролирующего \\
органа \\
- оказании \\
доминирующего \\
влияния на политику \\
предприятия в \\
соответствии с \\
договором \\
- на представительстве \\
большинства членов в \\
административном или \\
контрольном органе
\end{tabular} & $\begin{array}{l}\text { объектом инвестиций основан на: } \\
\text { - обладании полномочиями в } \\
\text { объекте инвестиций, под } \\
\text { которыми понимаются } \\
\text { существующие права, на } \\
\text { управление значимой } \\
\text { деятельностью в настоящий } \\
\text { момент времени; } \\
\text { - праве на получение переменного } \\
\text { дохода или подвергается рискам, } \\
\text { связанным с этим доходом от } \\
\text { участия в объекте инвестиций } \\
\text { - возможности влиять на } \\
\text { переменный доход при помощи } \\
\text { своих полномочий в отношении } \\
\text { объекта инвестиций }\end{array}$ & $\begin{array}{l}\text { предприятием существует, } \\
\text { если выполняется одно из } \\
\text { следующих условий: } \\
\text { - самостоятельное владение } \\
\text { большинством голосующих } \\
\text { акций - более 50\%; } \\
\text { - назначение или увольнение } \\
\text { большинство членов совета } \\
\text { общества, исполнительный } \\
\text { орган или большинство } \\
\text { членов исполнительного } \\
\text { органа и/или членов } \\
\text { ревизионной комиссии; } \\
\text { - оказание доминирующего } \\
\text { влияния на коммерческое } \\
\text { общество, на основании } \\
\text { договора или устава } \\
\text { общества. } \\
\text { [8, ст. 6, ст. 20] }\end{array}$ \\
\hline
\end{tabular}


продовження таблиці 1

\begin{tabular}{|c|c|c|c|}
\hline \multirow{2}{*}{$\begin{array}{c}\text { Поня- } \\
\text { тия }\end{array}$} & \multicolumn{3}{|c|}{ Определение понятий } \\
\hline & Директива 2013/34/EC [12] & IFRS 10 и IFRS 11 [11] & Директива 2013/34/EC [12] \\
\hline 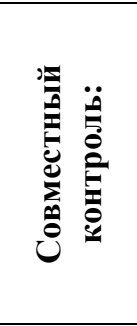 & $\begin{array}{l}\text { подразумевается, когда } \\
\text { предприятие совместно с } \\
\text { другим (другими), } \\
\text { которым принадлежат не } \\
\text { менее } 20 \% \text { голосов } \\
\text { акционеров, управляет } \\
\text { связанной стороной }\end{array}$ & $\begin{array}{l}\text { это разделенный контроль между } \\
\text { сторонами в соответствии с } \\
\text { договором, имеющий место в } \\
\text { случаях, когда } \\
\text { принятие решений касательно } \\
\text { значимой деятельности требует } \\
\text { единогласного согласия сторон }\end{array}$ & $\begin{array}{l}\text { подразумевается, когда } \\
\text { предприятие владеет } \\
\text { совместно с лицами, } \\
\text { действующими согласованно, } \\
\text { большинством голосующих } \\
\text { акций или долей участия в } \\
\text { коммерческом обществе [10, } \\
\text { ст. } 68]\end{array}$ \\
\hline 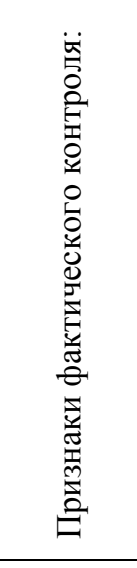 & $\begin{array}{l}\text { - наличие соглашений с } \\
\text { акционерами или } \\
\text { участниками группы; } \\
\text { - при доле участия не } \\
\text { менее } 20 \% \text { наличие } \\
\text { фактора управления на } \\
\text { унифицированной базе } \\
\text { или при наличии } \\
\text { административного или } \\
\text { контрольного органа }\end{array}$ & $\begin{array}{l}\text { на базе оценки доли прав голоса } \\
\text { инвестора в сравнении с долями и } \\
\text { их распределением среди } \\
\text { остальных правообладателей: } \\
\text { - договорное соглашение между } \\
\text { инвестором и другими } \\
\text { держателями прав голоса; } \\
\text { - права, предусмотренные } \\
\text { другими } \\
\text { - договорными соглашениями; } \\
\text { - сочетание договорных прав и } \\
\text { - потенциальных прав голоса }\end{array}$ & $\begin{array}{l}\text { - факт того, что инвестор } \\
\text { является акционером или } \\
\text { ассоциированной стороной } \\
\text { какого-либо предприятия и } \\
\text { самостоятельно владеет не } \\
\text { более } 40 \% \text { прав голос. } \\
\text { - является акционером или } \\
\text { участником коммер-ческого } \\
\text { общества и контролирует } \\
\text { самосто-ятельно не менее } \\
\text { 25\%, на основании } \\
\text { соглашения, за-ключенного с } \\
\text { другими акционерами[9, ст. } \\
68],[7, \text { ст. 26] }\end{array}$ \\
\hline 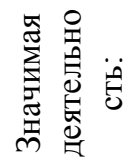 & $x$ & $\begin{array}{l}\text { деятельность объекта инвести-ций } \\
\text { которая оказывает значи-тельное } \\
\text { влияние на доход объекта } \\
\text { инвестиций }\end{array}$ & $x$ \\
\hline
\end{tabular}

*Источник: разработано авторами

Содержание законодательной и нормативной базы РМ демонстрирует строгое следование рекомендациям Директивы 2013/34/EC, в том числе и в отношении применения системы учета по справедливой стоимости для консолидированной отчетности. Это аргументируется большей значимостью данной системы оценки, чем основанной на цене приобретения или по фактическим затратам. Как известно, европейская модель бухгалтерского учета базируется на применении юридического подхода при подготовке отчетности, что обусловило ряд особенностей законодательной и нормативной базы РМ по сравнению с МСФО в отношении консолидации:

- признание и оценка отрицательного гудвилла;

- применение методов: при совместном контроле - пропорциональной консолидациии, при существенном влиянии - долевого участия;

- разрешение введения учета внутригрупповой передачи доли участия по методу объединения долей (метод слияния) [12].

В контексте второго аспекта исследования раскроем приемы установления формата контроля при консолидации согласно двум моделям бухгалтерского учета и отчетности. Так, согласно положениям, Директива 2013/34/ЕС (см. табл. 1) последовательно придерживается юридического подхода как в трактовке контроля, так и существенного влияния, основанных на оценочном показателе - доли участия. Директива четко указывает, что формат контроля при консолидации определяется наличием большинства голосующих акций, хотя допускает при определенных обстоятельствах и возможность получения фактического контроля. При совместном управлении, формат контроля ограничивается размером доли участия, при том что ее диапазон подразумевается от 20 до 50 процентов. Для предприятий, которые имеют долю участия более 20 процентов в другом предприятии и оказывают при этом на его деятельность существенное влияние, контроль как принцип подчиненности отсутствует. В этом случае подготовка консолидированной отчетности осуществляется согласно специфическому методу - долевое участие. Аналогичные требования обозначены в законодательной и нормативной базе РМ, что подтверждает ее принадлежность к европейской модели бухгалтерского учета (см. табл. 1). Как 
следствие, применение контроля при консолидации, основанном на оценочных показателях доли участия, ограничено. Отметим, что вопрос влияния юридического и экономического подходов на содержание финансовой отчетности подробно рассмотрен авторами в работе: [6, с. 91-108].

Теперь раскроем порядок определения формата консолидации согласно системе МСФО, которая как известно, ориентирована на использовании экономического подхода при подготовке финансовой отчетности. Кратко охарактеризуем порядок определения формата контроля, который представлен авторами в качестве алгоритма (рис.1). Итак, чтобы установить формат консолидации, необходимо определить, какая компания является материнской, при этом в качестве таковой, инвестор квалифицируется не однозначно только по причине обладания большинством голосующих акций, а при условии наличия контроля на основе полномочий в отношении объекта инвестиций.

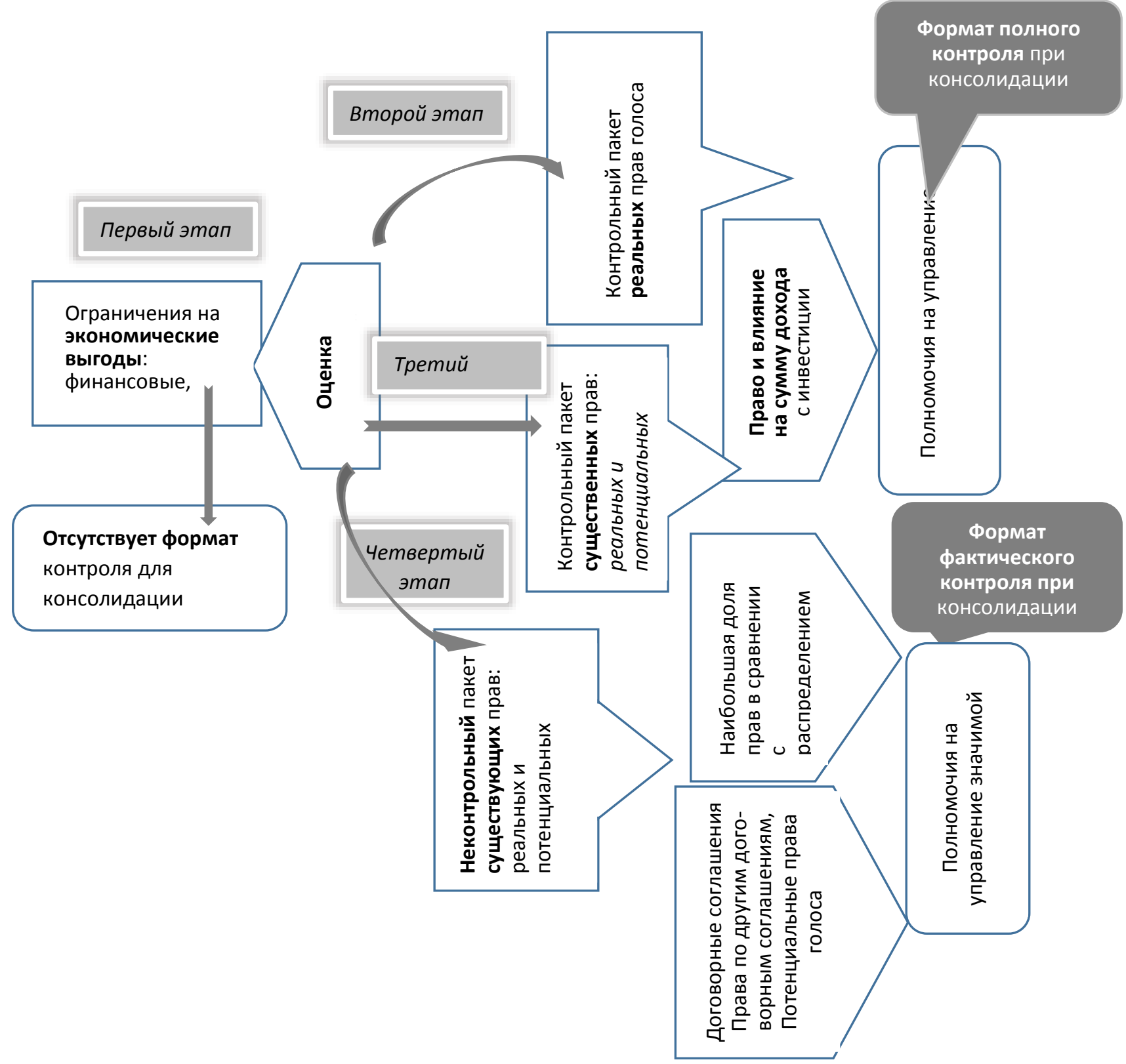

\section{Рис. 1. Алгоритм оценки полномочий для установления формата контроля при консолидации в соответствии IFRS 10 «Консолидированная финансовая отчетность» *Источник: разработано авторами}

В этом контексте уместно подчеркнуть, что в IFRS 10 вместо традиционного понятия «инвестируемая компания» намеренно используется понятие «объект инвестиций». По мнению авторов, данная трактовка отвечает принятому системой МСФО вектору 
экономического подхода при подготовке финансовой отчетности: при установлении формата контроля для консолидации акцент поставлен на управление экономическим эффектом от инвестиции (возврате или доходе), объектом которой является компания (экономический подход), а не на саму компанию как юридическую сторону участия в процессе инвестирования (юридический подход). В самом простом случае оценка полномочий инвестора, когда он является держателем контрольного пакета реальных прав голоса и обладает контролем над объектом инвестиций, при отсутствии каких-либо других факторов, не вызывает затруднений. Реальными являются те права, которые могут быть реализованы на текущий момент времени. Для установления их реальности необходимо применение профессионального суждения, например, для оценки такого обстоятельства как наличие барьеров экономического или иного характера, препятствующего субъекту права в реализации полномочий (первылй этап алгоритма).

Инвестор, если является держателем более половины прав голоса в объекте инвестиций, реальными в настоящий момент времени, располагает полномочиями посредством: голосования контрольного пакета прав голоса при управлении значимой деятельностью; назначения большинства членов органа управления, который осуществляет уначимой деятельностью (второй этап алгоритма). В рамках этого этапа необходимо установить, какая деятельность является значимой, что обусловлено минимизацией неопределенностей, которые возникают при определении контроля над объектом инвестиций. Так, неоднозначна оценка полномочий на базе потенциальных прав голоса в настоящий момент времени, и требуется рассмотрение ряда экономических и правовых фактов и обстоятельств и вынесение профессионального суждения по этому вопросу. В данном случае инвестор, оценивая свои полномочия, должен принимать во внимание структуру объекта инвестиций, что поможет установить: какие риски удерживаются объектом инвестиций, а какие - передаются другим сторонам; какая деятельность объекта инвестиций является значимой, и кто обладает возможностью ею управлять; какие стороны получают возврат на инвестиции (дивиденды, вознаграждения на обслуживание активов, другие выгоды) [11]. С целью нейтрализации неопределенностей при оценке полномочий предусмотрено исполнение двух других составляющих экономической сути контроля (табл. 1): права на переменную сумму возврата на инвестицию в значимую деятельность; использование своих полномочий для оказания влияния на сумму возврата на инвестицию (третий этап алгоритма).

Факт возврата на инвестицию очень важен, поскольку зачастую он является признаком контроля: чем больше степень подверженности инвестора рискам, связанным с переменными суммами возврата, тем больше стимул для инвестора получить права, обеспечивающие ему полномочия на управление значимой деятельностью. Таким образом, если неочевидно, что контроль обеспечивается правами голоса, то при установлении формата контроля при консолидации важным шагом в рамках третьего этапа алгоритма является идентификация значимой деятельности.

В соответствии с IFRS 10, даже если инвестор не является держателем большей долей пакета прав голоса в объекте инвестиций он может обладать полномочиями на базе фактического контроля (четвертый этап алгоритма). В этом случае для установления формата контроля необходимо оценить долю прав голоса, принадлежащую инвестору в сравнении с долями других правообладателей и принять во внимание распределение прав голоса среди них. Кроме этого, причиной возникновения полномочий на базе фактического контроля могут служить и другие факторы (см. рис.1).

В завершение раскрытия алгоритма оценки полномочий для установления формата контроля для консолидации, обозначим базовый тезис IFRS 10: тот инвестор, который имеет возможность в настоящий момент времени контролирует значимую деятельность объекта инвестиций (обладает полномочиями, которые обеспечивают ему единоличное принятие решений и распоряжений в отношении операционной и финансовой политики), и устанавливает формат контроля, даже если несколько инвесторов владеют правами на управление различными видами значимой деятельности. В этом заключается суть трактовки контроля согласно экономическому подходу подготовки консолидированной отчетности.

Итак, согласно унифицированной модели оценки контроля значение оценочного критерия для установления уровня подчинения (процентный порог) нивелируется, при этом акцент поставлен на возможности управления экономическим эффектом операций, связанных с участием в объекте инвестиций. Часть единой модели контроля применяется и при другом типе объединения - совместной деятельности, а принципы установления формата совместного 
контроля для подготовки консолидированной отчетности обозначены в IFRS 11 «Соглашения о совместной деятельности». Авторами уста- новление формата совместного контроля, как части единой модели контроля, на базе положений указанного стандарта представлено в рисунке 2.
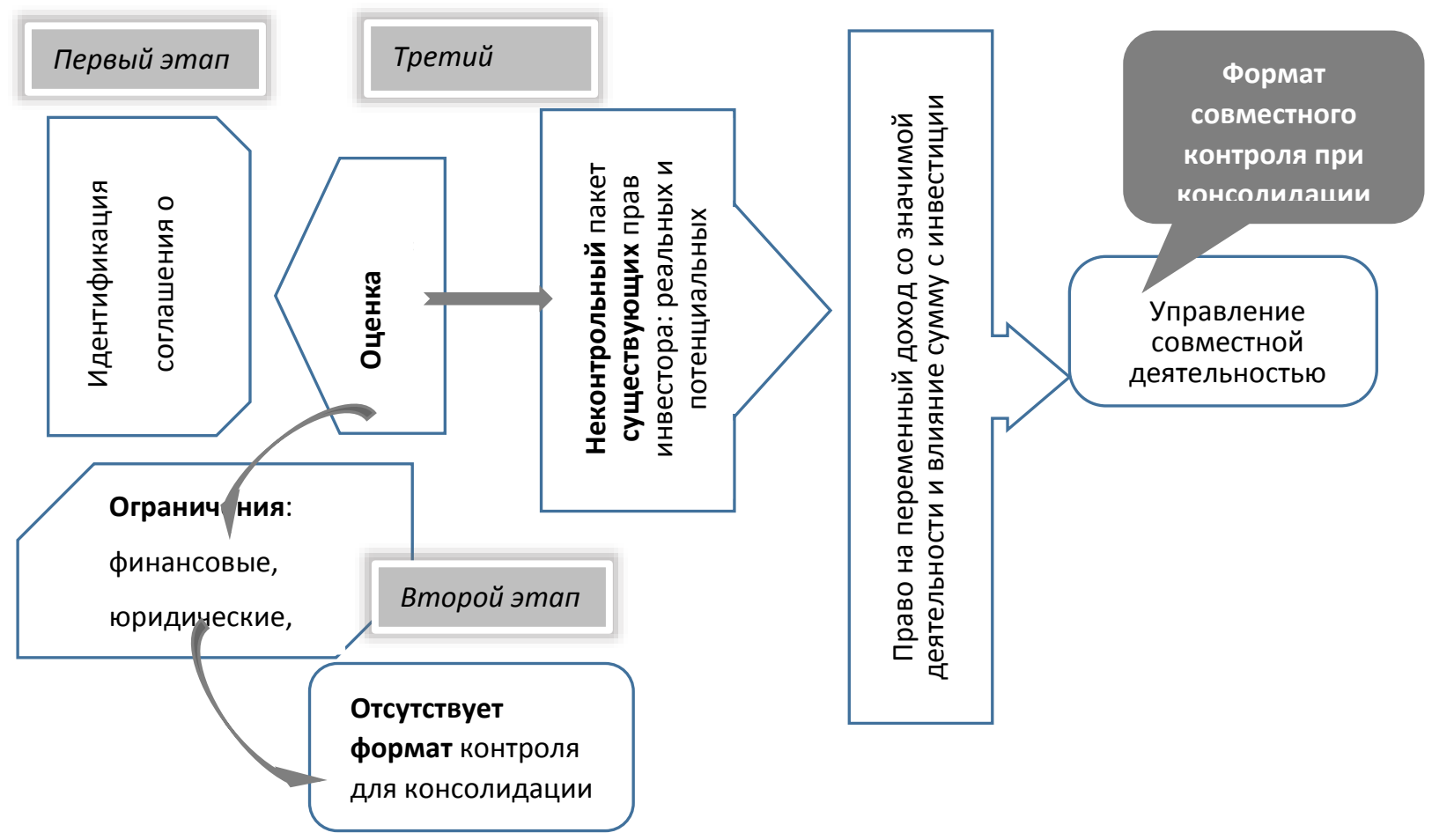

Рис. 2. Алгоритм оценки полномочий для установления формата контроля при консолидации в соответствии IFRS 11 «Соглашения о совместной деятельности»

*Источник: разработано авторами

Следует подчеркнуть, что существуют критические взгляды на применение унифицированной модели контроля: по мнению Аверчева И. новая концепция контроля более обширна, чем предыдущая, новое определение контроля имеет целью подтверждение того, что консолидированы все те предприятия, которые должны быть консолидированы на базе полномочий, но новая сущность контроля, позволит не включать в формат консолидации компании, данные по которым будут нежелательны для менеджмента объединения [1, c. 20]. В этом контексте авторы статьи считают уместным подчеркнуть, что согласно обозначенным стандартам от менеджеров компаний-инвесторов потребуется использование большого объема профессиональных суждений для определения контроля над объектом инвестиций или при определении того, кем осуществляется совместный контроль над деятельностью - всеми сторонами или группой сторон. Как известно, под профессиональным суждением понимается мнение составителя отчетности, вынесенное добросовестно и полезное для подготовки отчетности [6, с. 120].

В контексте третьего методологического аспекта исследования авторы придерживаются 218 мнения, что в настоящее время сложилось две концепции установления формата консолидации: первая - концепция управления, которая базируется на условии подчинения обусловленного долью участия; ее составляющими являются контроль, в том числе и фактический, совместное управление и существенное влияние; применение формата контроля при консолидации, основанного на оценочных показателях доли участия, носит ограниченный характер, что вполне отвечает принципу точности информации, превалирующим при юридическом подходе подготовки финансовой отчетности, используемого европейской моделью бухгалтерского учета; вторая - концепция единого контроля, основывается на объеме полномочий, обусловленных общей экономической выгодой, которая должна быть получена инвестором от объекта инвестиций. Составляющими этой концепции являются полный контроль, фактический и совместный контроль. Концепция отвечает принципам достоверности и приоритета содержания над формой - базовым принципам экономического подхода, на котором основывается 
международная (англо-саксонская) модель бухгалтерского учета.

Выводы и перспективы дальнейших исследований. При инновационном векторе развития в условиях ограничения ресурсов одним из путей решения этой проблемы является организация бизнес-структуры на базе слияния капиталов различных бизнес-единиц. Поскольку менеджмент бизнес-структуры, а также ее акционеры и инвесторы нуждаются в достоверной информации о финансовом положении и финансовых результатах такого объединения необходимо при подготовке консолидированной отчетности использовать специальные приемы, один из которых - это установления формата контроля при консолидации.

С целью аргументации действенности гипотезы о двух концепциях установления формата консолидации: концепции управления (европейская модель учета) и концепции контроля (международная модель учета), в современной методологии бухгалтерского учета, в первой части исследования авторами с позиции нормативного регулирования проведено их сравнение: Директивы 2013/34/EC и законодательства PM, и IFRS 10
«Консолидированная финансовая отчетность», IFRS 11 «Соглашения о совместной деятельности». Однако для решения этой проблемы необходимо понимание особенностей концепций, сущность которых проявляется в приемах установления формата контроля при консолидации, используемых в рамках юридического и экономического подхода. Для этого в рамках второго этапа работы раскрыт каждый из приемов, регламентированный соответствующим регулятивом. В этой части исследования авторами разработан алгоритм, демонстрирующий механизм установления формата консолидации на базе единой концепции контроля. Полученные результаты исследования аргументируют истинность выдвинутой гипотезы о применении двух концепций формата консолидации, характеристика которых приведена в третьей части работы. Однако существует еще ряд проблем, имеющих отношение к применению новой концепции контроля при консолидации, и в первую очередь - это действенность механизма установления формата контроля при подготовке консолидированной отчетности.

\section{ПЕРЕЧЕНЬ ИСПОЛЬЗОВАННЫХ ИСТОЧНИКОВ}

1. Аверчев И. МСФО (IFRS) 10 «Консолидированная финансовая отчетность». 2012, с. 10-21. Режим доступа: https://elibrary.ru/full_text.asp?id=20375497

2. Василевич Д. Консолидированная отчетность в системе бухгалтерской (финансовой) отчетности, 2017, с. 125 127. Режим доступа: https://elibrary.ru/full_text.asp?id=32788...79

3. Генералова Н. Истоки и эволюция консолидированной финансовой отчетности в России//Н. Генералова, С. Карельская/ Вестник Санкт-Петербургского университета, 2015, серия 5, выпуск 2, с. 90-111

4. Плотников В., Юсупова И. Консолидированная и сегментарная финансовая отчетность группы компаний, 2014, c. 10-17. Режим доступа: https://elibrary.ru/full_text.asp?id=21438...65.

5. Сигидов Ю., Мороз Н. и др. Консолидированная отчетность - как продукт эволюции мировой экономической системы, 2018, с. 304-312. Режим доступа: https://elibrary.ru/full_text.asp?id=36555405

6. Цуркану, В. Концептуальные основы формирования баланса организации. В: монографии «Розвиток концепції бухгалтерського обліку на основі інституційних підходів та бенчмаркингу»/ Монографія /В., Цуркану, И., Голочалова/ За заг. ред. д.е.н., проф.. Бутинця Ф.Ф. - Житомир «Рута», 2015. - 395с.

7. Закон №1134 - XIII от 02.04.1997 г. Республики Молдова об акционерных обществах (с последними изменениями от $\quad$ 08.11.2018 $\quad$ г.). Режим доступа: http://www.lex.justice.md/viewdoc.php?action=view\&view=doc\&id=32651

8. Закон № 171 от 11.07.2012 Республики Молдова о рынке капитала (с последними изменениями на 01.11.2018 г.). Режим доступа: http://lex.justice.md/ru/344790/

9. Закон № 287 от 15.12.2017 года Республики Молдова О бухгалтерском учете и финансовой отчетности с последними дополнениям и изменениям. http://www.lex.justice.md/viewdoc.php?action=view\&view=doc\&id=37360

10. Гражданский кодекс № 1107 от 06.06.2002 Республики Молдова с последними изменениями от 15.11.2018 г. с последними дополнениями и изменениями. Режим доступа: http://lex.justice.md/ru/325085/
11. Международные стандарты финансовой
отчетности
(МСФО).
Режим
доступа:

http://www.mf.gov.md/ru/lex/contabilitate-\%C8\%99i-audit

12. Directive 2013/34/EU of European Parliament and of the Council of 26 June 2013 'On the annual financial statements, consolidated financial statements and related reports of certain types of undertakings'. Retrieved from : http://eur-lex.europa.eu/LexUriServ

13. C.-Al. Baltariu, A. Cirstea. Harmonization of goodwill reporting practice in the consolidated financial statements of Romanian groups. Annales Universitatis apulensis series Oeconomica, 14 (2), 2012, p. 311-319 
14. V. Voskalo, Z. Skybinska, N. Voskalo. Current problems of preparetion and presentation of consolidated financial statements. International conference 2017. 17-19 May, 2017, Lublin, c. 531-532, Retrieved from : http://www.toknowpress.net/ISBN/pape...

\section{REFERENCES}

1. Averchev, I. (2012). MSFO 10 «Consolidirovannaya finansovaya otchiotnost'» [IFRS 10 «Consolidated financial reports»]. elibrary.ru. Retrieved from: https://elibrary.ru/full_text.asp?id=20375497 [in Russian].

2. Vasilevich', D. (2017). Consolidirovannaya otchiotnost' v sisteme buhgalterskoy (finansovoy) otciotnosti [The consolidated reports in the accounting (financial) system]. elibrary.ru. Retrieved from: https://elibrary.ru/full_text.asp?id=32788...79 [in Russian].

3. Generalova, N., \& Carel'scaya, S. (2015). Istoki i evoliutsiya consolidirovannoy finansovoy otchiotnosti v Rossii [The origins and development of consolidated financial reports in Russia]. Vestnik Sankt-Peterburgskogo universiteta Bulletin of St. Petersburg University, 2, 90-111 [in Russian].

4. Plotnicov, V., \& Yusupova, I. (2014). Consolidirovannaya i segmentarnaya finansovaya otchiotnost' grupy companiy [The consolidated and segmental financial reports of group of companies]. elibrary.ru. Retrieved from: https://elibrary.ru/full_text.asp?id=21438...65 [in Russian].

5. Sigidov, Yu., \& Moroz, N., \& Guseva, N. (2018). Consolidirovannaya otchiotnost' kak product evoliutsii mirovoy economicheskoy sistemy [The consolidated statements as a product of the world economic system]. elibrary.ru. Retrieved from: https://elibrary.ru/full_text.asp?id=36555405 [in Russian].

6. Tsurcanu, V., \& Golochalova, I. (2015). Conceptual'nye osnovy formirovaniy balansa organizatsiy. V: Monografia «Razvitie contseptsiy buhgalterskogo ucheta na osnove institutsional'nyh podhodov I benchmarcinga». [Conceptual framework for the formation of entity balance sheet. In: Monograph «The evolution of the concepts of accounting is based on the institutional approaches and benchmarking»]. Zhytomyr: «Ruta», 89-166 [in Russian].

7. Zakon № 1134-XIII ot 02.04.1997 g. Respubliki Moldova «Ob actsionernyh obschestvah» [Law of the Republic of Moldova «On the joint-stock companies»]. (1997, April 02). lex.justice.md. Retrieved from: http://www.lex.justice.md/viewdoc.php?action=view\&view=doc\&id=326515 [in Russian].

8. Zakon № 171 ot 11.07 .2012 g. Respubliki Moldova «O rynke capitala» [Law of the Republic of Moldova «On the capital market]. (2012, July 11). lex.justice.md. Retrieved from: http://lex.justice.md/ru/344790/ [in Russian].

9. Zakon № 287 ot 15 dekabrya 2017 g. Respubliki Moldova «O buhgalterskom uchete i finansovoy otchentosti» [Law of the Republic of Moldova «On Accounting and financial reports»]. (2017, December 15). lex.justice.md. Retrieved from: http://www.lex.justice.md/viewdoc.php?action=view\&view=doc\&id=373601 [in Russian].

10. Grajdanskiy Kodeks № 1107 ot 06 iyunya 2002 g. Respubliki Moldova [Civil Code of the Republic of Moldova]. (2002, June 06). lex.justice.md. Retrieved from: http://lex.justice.md/ru/325085/ [in Russian].

11. Mejdunarodnye standarty finansovoy otchiotnosti [International Financial Reporting Standards]. mf.gov.md. Retrieved from: http://www.mf.gov.md/ru/lex/contabilitate-\%C8\%99i-audit [in Russian].

12. Directive 2013/34/EU of European Parliament and of the Council «On the annual financial statements, consolidated financial statements and related reports of certain types of undertakings» (2013, June 26). eur-lex.europa.euю Retrieved from : http://eur-lex.europa.eu/LexUriServ [in English].

13. Baltariu C.-Al., \& Cirstea, A. (2012). Harmonization of goodwill reporting practice in the consolidated financial statements of Romanian groups. Annales Universitatis apulensis series Oeconomica, 14 (2), 311-319 [in English].

14. Voskalo, V., \& Skybinska, Z., \& Voskalo N. (2017). Current problems of preparation and presentation of consolidated financial statements. International conference, Lublin, 531-532. toknowpress.net. Retrieved from: http://www.toknowpress.net/ISBN/pape [in English].

Одержано 14.03.2019 